\title{
ASSESSING THE EFFECTS OF FOREIGN FINANCIAL SHOCKS ON THE CHILEAN ECONOMY
}

\section{EVALUANDO LOS EFECTOS DE SHOCKS FINANCIEROS EXTERNOS SOBRE LA ECONOMIA CHILENA}

\section{FRANCISCO CABEZON*}

Superintendency of Banks and Financial Institutions - Chile**

\begin{abstract}
This paper aims to assess the effects offoreign financial shocks on the Chilean economy, for which a model including foreign and domestic series, for both real and financial variables at quarterly frequency is estimated. Among the main results, it is found that Chilean GDP is negatively and significantly affected by shocks in the volatility of foreign stock markets, while the Chilean currency depreciates and the domestic interest rate decreases due to this type of innovations.
\end{abstract}

Keywords: Foreign financial shocks, volatility, foreign stock markets, domestic variables, Chilean economy.

JEL Classification: E44, F41, G01.

\section{Resumen}

Este artículo tiene por objetivo evaluar los efectos de shocks financieros externos sobre la economía chilena, para lo cual se estima un modelo que incluye series externas y domésticas, para variables reales y financieras en frecuencia trimestral. Entre los principales resultados, se encuentra que el PIB chileno es afectado negativa y significativamente por shocks en la

* This work was started at Queen Mary, University of London. I am grateful to Ana Beatriz Galvao (Ph.D.), for her helpful advices on a preliminary version of this paper. I also appreciate the comments made by an anonymous referee. All remaining errors are my own. E-mail: fcabezon@sbif.cl.

** The views expressed in this paper are those of the author and do not necessarily represent the views of the Superintendency of Banks and Financial Institutions of Chile. 
volatilidad de los mercados accionarios externos, mientras que la moneda chilena se deprecia y la tasa de interés doméstica desciende debido a este tipo de innovaciones.

Palabras Clave: Shocks financieros externos, volatilidad, mercados accionarios externos, variables domésticas, economía chilena.

Clasificación JEL: E44, F41, G01.

\section{INTRODUCTION}

During the late 2000s, stock markets in several countries were characterized by an important fall in their returns and an increasing volatility. The negative returns could be seen during 2008 and a significant part of 2009, while the high volatility could even be seen during part of 2010. Specifically, both the Dow Jones (total) index and the MSCI World index -which includes the equity markets of 24 developed markets- exhibited negative returns from 2008Q1 to 2009Q3, while their coefficients of variation still showed in 2010 a peak in the second quarter, as can be seen in Figure 1.

Also during 2009, several economies experienced negative growth rates, a situation that involved both developed and emerging countries all over the world.

Among the developed economies, the GDP of the United States fell by $3.5 \%$, the European Union exhibited a $4.4 \%$ drop in growth, and the output of OECD member countries fell by $3.8 \%$ (in total) during the same period ${ }^{1}$.

Several emerging economies also had negative performances in 2009. Among them, Chile which got the only negative value in its GDP growth rate since 1999-when it was affected by the Asian crisis- decreasing $1.0 \%$. The growth rate of the Chilean GDP from 1996 to 2010 is shown in Figure 2.

In order to explain the performance of the Chilean Economy during 2009, it must be considered that exports represent roughly $30 \%$ of the Chilean GDP ${ }^{2}$; therefore, a fall in the GDP of foreign economies -and especially in those that demand Chilean products- is likely to produce a subsequent fall in Chilean GDP. Because of this, it might be stated that a significant part of the negative performance of the Chilean Economy during 2009 could be explained by the global recession; however, several questions regarding the role of some financial variables can be asked.

Apart from the possible effect of foreign real variables on the Chilean economy, are shocks in international stock markets able to explain part of the fluctuations of the Chilean GDP? If so, how rapid is this response? And finally, how are other domestic variables affected by these types of innovations?

All values were obtained from the OECD.

2 It corresponds to the average of Exports over GDP (both values at constant prices), for the period 1986-2010. Author's calculation based on data obtained from the Central Bank of Chile website. 


\section{FIGURE 1}

\section{RETURNS (UPPER GRAPH) AND COEFFICIENTS OF VARIATION (LOWER GRAPH) OF DOW JONES TOTAL INDEX AND MSCI WORLD INDEX}
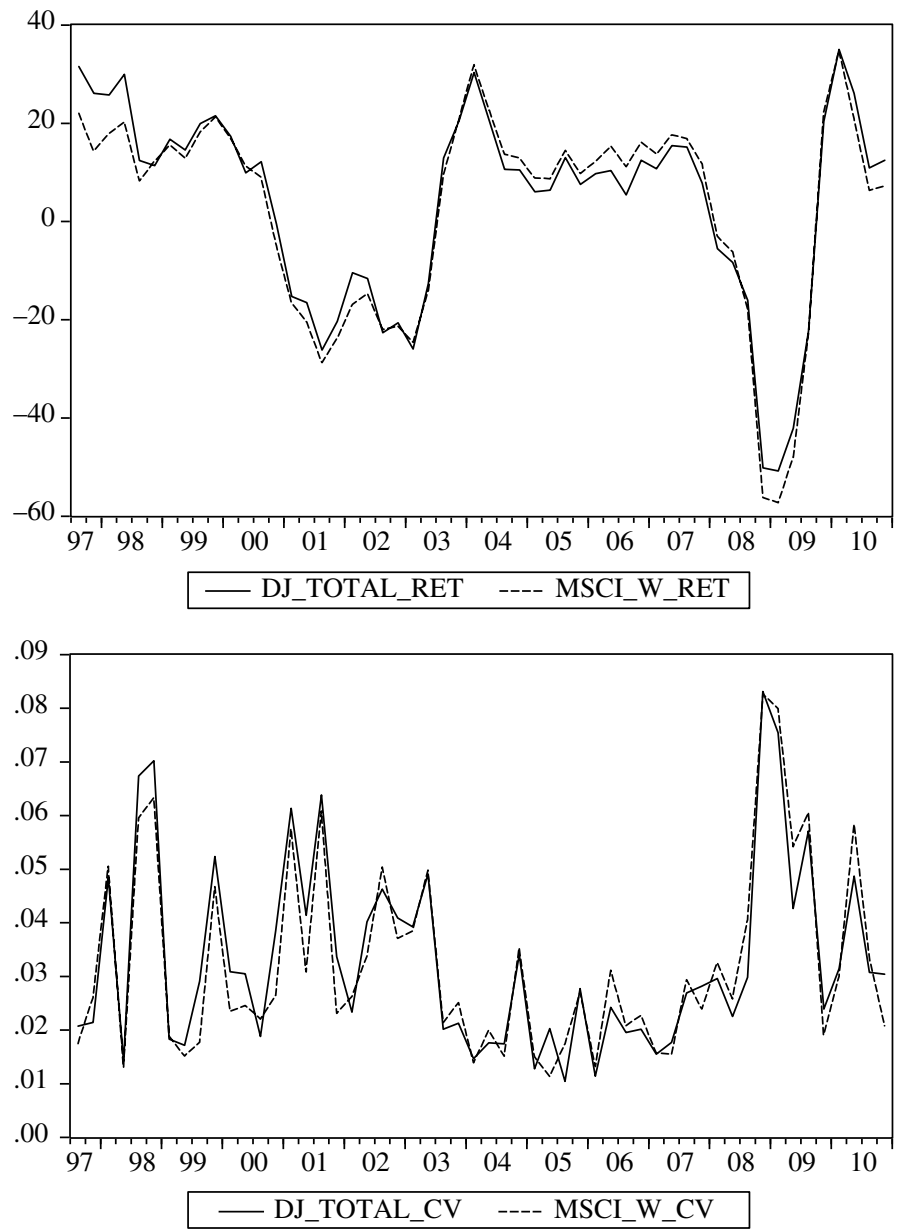

Source: Author's calculation based on data obtained from DataStream.

These questions represent the main motivation of this paper, and in order to answer them a VAR model for the Chilean economy is estimated. The dataset used here includes foreign and domestic series, for both macroeconomic and financial variables. In order to capture the velocity of the responses the dataset is expressed 


\section{FIGURE 2}

\section{GROWTH RATE OF THE CHILEAN GDP}

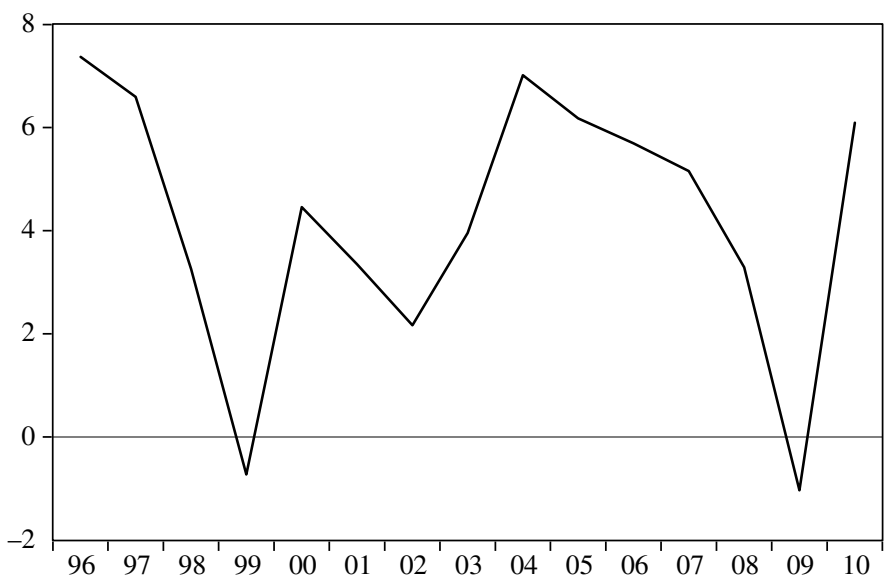

Source: Author's elaboration, based on data obtained from the OECD.

at quarterly frequency, and in order to capture the dynamics experienced during the global financial crisis the series cover the period between 1997Q3 and 2010Q4.

This paper is structured as follows: Section II covers a literature review of both international and Chilean articles, Sections III and IV correspond to the data and our methodology respectively, in Section $\mathrm{V}$ the main results are shown, and finally in Section VI key conclusions are expressed.

\section{LITERATURE REVIEW}

In the international literature there exists a wide variety of papers in which the effects of financial indicators on macroeconomic variables have been measured, and among them there are several examples of DSGE models.

There is an important precedent of models including financial frictions which have focused on the role of these types of indicators - as mentioned by Rapach and Strauss $^{3}$ - in propagating and amplifying different shocks, but they have not been concerned with the effects that these shocks have in the financial sector per se.

3 In their presentation made at the Midwest Econometrics Group Meetings, Chicago, USA, October 2011 (Preliminary version of the paper coming soon). 
In this group of articles, Bernanke, Gertler and Gilchrist (1999) developed a dynamic general equilibrium model to explain the role of credit market frictions in business fluctuations, whose framework exhibited a financial accelerator. Their results showed that under some parametrizations, this accelerator had a significant influence on business cycle dynamics.

In some more recent articles -also mentioned by Rapach and Strauss- DSGE models have included explicit financial frictions and exogenous financial sector shocks. Among them, Gilchrist, Ortiz and Zakrajšek (2009) estimated a DSGE model to quantify the role of financial frictions in business cycle fluctuations. Their results -for the period 1973 to 2008- showed that increases in the external finance premium caused significant declines in output, providing evidence that financial frictions have played an important role in U.S. cyclical fluctuations.

Also using these type of models, there are papers that have focused on more particular financial topics. Jermann and Quadrini (2009) for instance, using a general equilibrium model showed that financial shocks affecting a firm's capacity to borrow can better fit the data compared to those with standard productivity shocks, which can only explain part of the observed fluctuations in real variables.

In Chile, as Chumacero and Schmidt-Hebbel (2004) have stated, there has been a long sequence of articles helping to develop a better characterization of the Chilean Economy by using general equilibrium models. Following this line of articles Caputo, Medina and Soto (2010) used a new Keynesian DSGE model, by including use of an external finance premium which amplified the responses to different shocks. In their results, they found that financial frictions have played an important role in amplifying business cycle fluctuations.

In a more recent paper, Caputo, Medina and Soto (2011) analyzed the effects of the global financial crisis on the Chilean economy with a DSGE model that incorporated financial restrictions (domestic spread and country risk premium shocks). The authors found that foreign shocks -the spread differential, the country risk premium and foreign output shocks- played a major role in the downturn experienced by Chile in 2008 and 2009.

With a different approach, there also exist papers in which VAR models have been used in order to assess the interaction between financial and macroeconomic variables. Among the most recent of these papers, Rapach and Strauss (forthcoming) analyze the empirical relevance of financial sector shocks for business-cycle fluctuations in G-7 countries. They found that financial sector shocks are important for fluctuations in industrial production, especially during the global financial crisis.

In a similar article, but focusing on a small and open economy, Buckle et al. (2002) developed a model for New Zealand. The international variables were block exogenous in their model, and restrictions on contemporaneous and lagged variables were included. The model was estimated using deviations from the trend with quarterly data from 1983Q1 to 2002Q1, and took into account thirteen foreign and domestic variables, including foreign and domestic real assets returns, besides foreign and domestic interest rates. Among their results, they found that an increase in the return of world equities caused an increase in return of domestic equities as well as an increase in the domestic demand and domestic output, and a rise of the domestic interest rate. 
It is worth mentioning that this latter paper implements techniques developed by Cushman and Zha (1997), who proposed a model to identify the effects of monetary policy shocks that explicitly accounted for the features of a small and open economy. These authors separated foreign and domestic variables into two different blocks, and imposed a so called "block exogeneity" restriction, which implies that the block with the foreign variables does not enter into the block of the domestic ones either contemporaneously or in lagged terms.

In Chile, VAR models have been widely used, especially in topics related to stabilization and monetary policy transmission. Among them, Valdés (1997) used semi-structural VARs to present empirical evidence regarding Monetary Policy operation in Chile. Parrado (2001) developed a Structural VAR for the Chilean Economy imposing contemporaneous plausible restrictions to identify structural shocks, and including variables representing inflationary pressures. Mies, Morandé and Tapia (2002) analyzed both the development of impulse-response functions and the impact of monetary policy on various productive sectors. Jaramillo (2008) estimated Bayesian Vector Autoregressive models for the Chilean economy, evaluating transmission mechanisms of the monetary policy besides forecasting key macroeconomic variables. Finally, Catão and Pagan (2010) used an expectation-augmented SVAR to study monetary transmission in both Brazil and Chile, incorporating key structural features of emerging economies.

Regarding the goal of this paper, Franken, Le Fort y Parrado (2005) used a VAR model to analyze the response of the Chilean business cycle to different shocks. In their article they used yearly data for the period 1950-2003, and introduced block exogeneity into the lag structure of the model using a set of twelve variables, most of which were measured as deviations from their long-term trend. Real and financial variables for both foreign and domestic series were considered, including standard deviation for foreign stocks and real returns for domestic ones. Among their results, they found that increases in the volatility of foreign equities had a negative impact on the real return of Chilean equities, caused a decline in capital flows, and had a negative effect on the business cycle.

More recently, Gonzalez (2012) developed a Large Bayesian VAR for the Chilean Economy, including over 100 variables at monthly frequency covering the period 1996:1-2009:12. Financial variables were included; however, the analysis is focused on - among other topics- the effect of shocks in the domestic stock market, rather than on the effect of foreign financial shocks.

To conclude, it can be stated that foreign financial variables have been included in several papers on the Chilean economy, using both DSGE and VAR models. However, the effects of foreign stock market shocks on the Chilean economy -as far as this revision was able to find- seem not to have been completely studied, because the papers have not explicitly included these variables, because they have not fully considered the period of the recent global financial crisis, or because they have used datasets that have not been able to accurately describe this matter.

This paper aims to assess the effect of disturbances in foreign stock markets on some of the main Chilean macroeconomic variables, using a dataset that is explained in the following section. 


\section{DATA}

The dataset contains ten time series, covering quarterly the period between 1997Q3 and 2010Q4. In order to describe them, these variables can be divided into two different groups: the first, a group of international variables, representing foreign real and financial variables potentially affecting the Chilean economy and the second, a group of domestic variables, which capture the effect of domestically produced shocks ${ }^{4}$.

Among the international variables, the first series $\left(Y^{W}\right)$ was computed as the weighted average of the growth rates of countries that represent the main destinations for Chilean exports. As it was previously stated, exports represent roughly 30 per cent of the Chilean GDP; therefore, this variable aims to measure the effect of variations in the demand for Chilean exports.

The second variable $\left(R^{W}\right)$ represents the foreign interest rate, and was calculated as the weighted average of the three month interbank offer rate (or the rate associated with Treasury bills) of the five largest world economies for the period. This variable -along with the domestic interest rate- attempts to capture the effect of shocks produced by the interest rate differential, when it is not offset by the expectations regarding the exchange rate.

The third variable represents the foreign stock markets $\left(S^{W}\right)$ and was computed using the MSCI World index, which represents the performance of stock markets in 24 developed economies. The coefficient of variation of this index -computed as the standard variation over the mean within each period- was calculated and included in the dataset, attempting to capture the effect of the volatility of foreign stock markets on the Chilean economy.

The importance of exports for the Chilean economy has been already stated; nevertheless, it is also necessary to mention that the ratio of imports to the Chilean GDP is roughly $0.3^{5}$. The fourth and fifth variables are intended to measure the effect of terms of trade on the Chilean economy, and considering that this time series for Chile is only available at quarterly frequency from 2003 onwards, international prices of Copper $\left(C^{W}\right)$ and Oil $\left(O^{W}\right)$ are included in the dataset. These two variables represent roughly 43 and 27 percent of exports and imports respectively for the period, at current prices ${ }^{6}$.

Among the domestic variables, the sixth series stands for the growth rate of the Chilean Economy $\left(Y^{D}\right)$, which was computed with a spliced series -base 2003- at constant prices and seasonally adjusted. This variable is used to measure the impact of foreign stock market shocks on the Chilean quarterly GDP.

The seventh variable stands for domestic prices $\left(P^{D}\right)$, and corresponds to the historical series for the Headline Chilean CPI. The next series represents the domestic interest rate $\left(R^{D}\right)$, and represents the three month interbank offer rate (or the rate associated with Treasury bills) in the Chilean economy.

Details for each one of these series can be found in the Appendix.

Author's calculation based on data published by the Central Bank of Chile.

Author's calculation based on data published by the Central Bank of Chile. 
The ninth series stands for a multilateral and nominal exchange rate $\left(E^{D}\right)$, which is computed by the Central Bank of Chile and is intended to measure the effect of variations in the exchange rate on Chilean exports and imports, and subsequently on the Chilean GDP.

Finally, the last series represents the domestic stock market $\left(S^{D}\right)$, and was computed with the index IPSA, which is composed of the 40 most heavily traded stocks in The Santiago Stock Exchange. This series -symmetrically to the series included for foreign stock markets- represents the coefficient of variation of this index, and captures the effect of domestically driven stock market shocks.

It is worth mentioning that in some cases these series represent the longest range available at quarterly frequency; so, although it was desirable to estimate a model including more observations, this was not possible for all of the series.

In the following figures the co movements among some of the variables are shown, starting with Figure 3 that displays the volatility of foreign stocks, along with the Chilean GDP and the GDP of those countries that demand Chilean exports more intensively.

The GDP of Chile mostly follows the movements of the GDP of those countries that demand Chilean exports more intensively; however, peaks and drops in the Chilean GDP are not always related to movements in this foreign GDP, as can be seen in 1999 and 2005. Besides, the fall in Chilean GDP in 2009 is larger than the fall of the main recipients of Chilean exports. On the other hand, the Chilean GDP and the volatility of

FIGURE 3

FOREIGN STOCKS VOLATILITY, CHILEAN GDP, AND GDP OF CHILEAN EXPORTS DEMANDERS

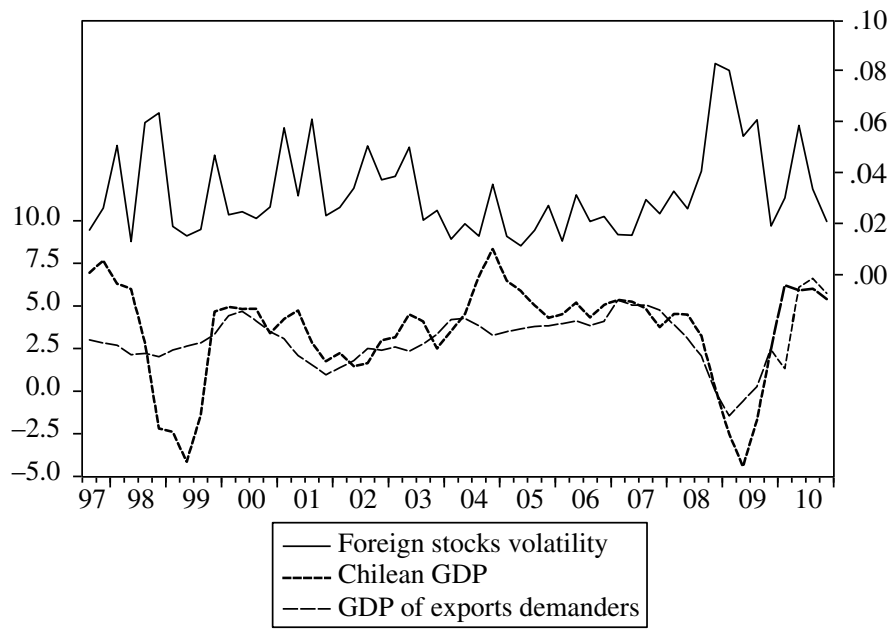

Source:Author's elaboration, based on data obtained from DataStream and from the Central Bank of Chile, among others sources (see the Appendix for more details). 
foreign stock markets seem to move for the most part in opposite directions, and the two lowest troughs in Chilean GDP are related to peaks in the volatility of foreign stocks.

Figure 4, shows volatilities of both foreign and domestic stocks, along with the exchange rate. Domestic and foreign stocks volatilities move mostly together; however, there is an important peak in the domestic volatility in 1998 which is not accompanied by a shock in the foreign volatility, and from 2006 onwards these two variables do not precisely follow a common pattern. On the other hand, some of the rises in the exchange rate -especially during the period of the global financial crisis- seem to be related to increases in the volatility of foreign and domestic stocks.

The movements of Chilean GDP with respect to prices of Copper and Oil show dissimilar results, as can be seen in Figure 5. On the one hand, movements in the international price of Copper seem to have the expected result: in general, increases in the price of this metal are related to increases in the Chilean GDP (and vice versa), with the remarkable exception of 1999. On the other hand, considering that Oil is an input for Chilean producers, increases in its international price should also represent increases in their costs; subsequently, a fall in the Chilean GDP should be expected. However, the Chilean GDP and the international price of Oil move closely together, especially from 2000 onwards.

To conclude, Table 1 shows means and standard deviations of the variables, along with the correlation between each one of them and the growth rate of the Chilean GDP.

\section{FIGURE 4}

\section{DOMESTIC STOCKS VOLATILITY, FOREIGN STOCKS VOLATILITY,} AND EXCHANGE RATE

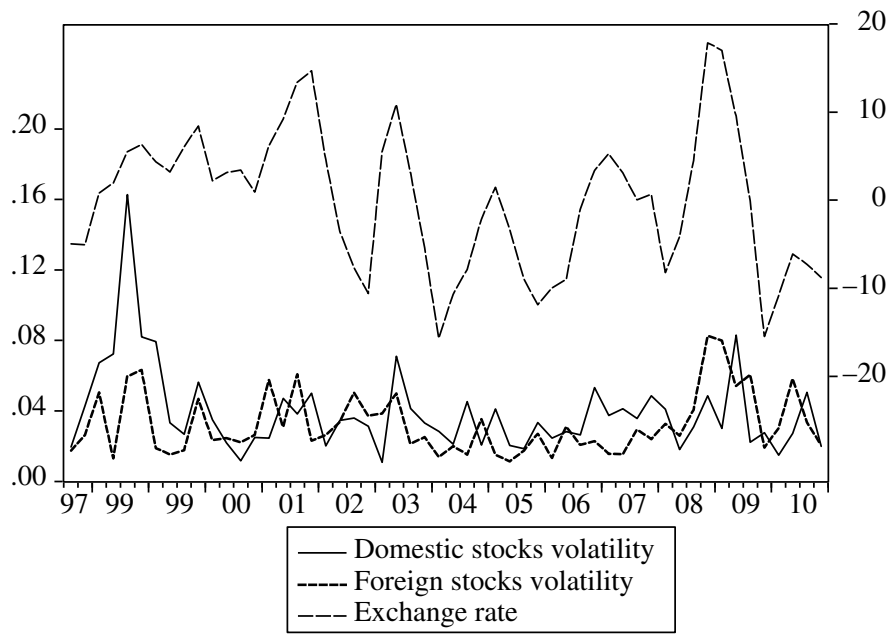

Source: Author's elaboration, based on data obtained from DataStream and from the Central Bank of Chile. 


\section{FIGURE 5}

\section{CHILEAN GDP AND PRICES OF COPPER AND OIL}

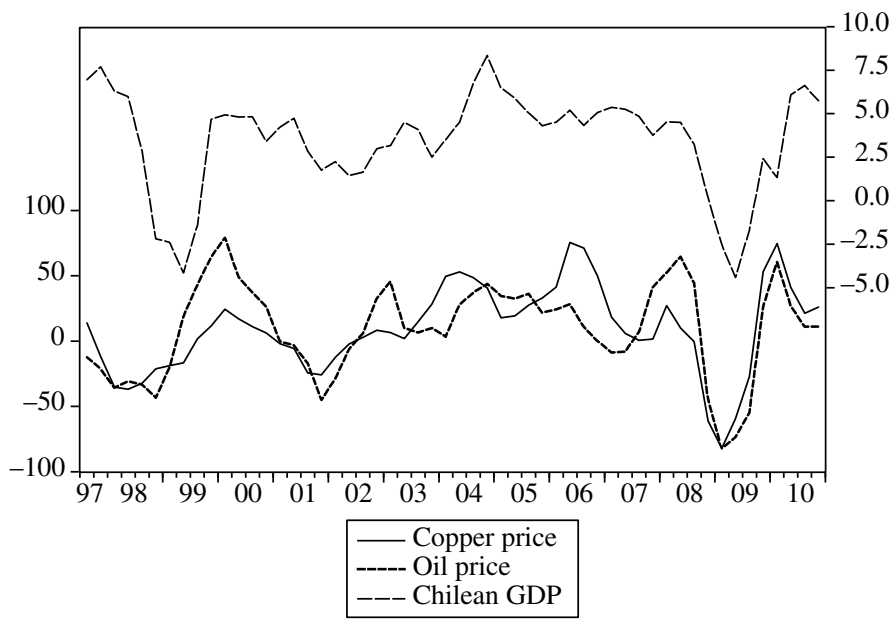

Source: Author's elaboration, based on data obtained from the Central Bank of Chile.

\section{TABLE 1}

MEANS, STANDARD DEVIATIONS, AND CORRELATIONS WITH RESPECT TO THE GROWTH RATE OF THE CHILEAN GDP

\begin{tabular}{|c|c|c|c|c|c|c|c|c|c|c|}
\hline & $\begin{array}{l}\text { Demand } \\
\text { for } \\
\text { Chilean } \\
\text { exports }\end{array}$ & $\begin{array}{c}\text { Foreign } \\
\text { Interest } \\
\text { Rate }\end{array}$ & $\begin{array}{c}\text { Foreign } \\
\text { Stock } \\
\text { markets }\end{array}$ & Copper & Oil & $\begin{array}{l}\text { Growth } \\
\text { Rate } \\
\text { Chile }\end{array}$ & $\begin{array}{c}\text { Domestic } \\
\text { prices }\end{array}$ & $\begin{array}{c}\text { Domestic } \\
\text { interest } \\
\text { rate }\end{array}$ & $\begin{array}{l}\text { Exchange } \\
\text { rate }\end{array}$ & $\begin{array}{c}\text { Domestic } \\
\text { Stock } \\
\text { markets }\end{array}$ \\
\hline Mean & 3.14 & 2.96 & 0.03 & 8.92 & 9.38 & 3.47 & 3.45 & 6.29 & -0.04 & 0.04 \\
\hline Std. Dev. & 1.58 & 1.36 & 0.02 & 33.22 & 35.84 & 2.92 & 2.16 & 4.50 & 8.03 & 0.02 \\
\hline $\begin{array}{l}\text { Correlation } \\
\text { with the } \\
\text { Growth } \\
\text { rate of } \\
\text { Chilean } \\
\text { GDP }\end{array}$ & 0.60 & 0.22 & -0.37 & 0.51 & 0.43 & 1.00 & 0.04 & -0.03 & -0.37 & -0.19 \\
\hline
\end{tabular}

Source: Author's calculation, based on data obtained from different sources (see the Appendix for more details). 


\section{METHODOLOGY}

The aim of this paper is to describe the effects of foreign stock market shocks on the Chilean Economy, including explicitly these types of innovations in a VAR model, and using a dataset that, due to its frequency and extension, captures the dynamics of the Chilean economy during the global financial crisis. This paper focuses on a statistical approach and does not try to propose a model based on a macroeconomic structure as those made through implementing DSGE models.

However, before starting the description of the methodology it is worth mentioning some of the limitations of VAR models. As García, Gonzalez and Moncado (2010) stated, in these models usually many parameters need to be calculated, which is frequently difficult due to the lack of data and it is often necessary to choose some method of imposing restrictions on the parameters. Besides, as mentioned by Cushman and Zha (1997), identification has been a source of problems in these models, especially in the case of small open economies.

Taking into account these limitations, the model implemented in this paper has been tested in several ways -which are detailed later in this section- and needs to be understood as a general and statistical way of describing the effects of foreign stock market shocks on the Chilean economy.

The VAR model implemented here uses the series described in the previous section, which are organized in the following vector of variables:

$$
Y_{t}=\left[\begin{array}{lllllllllll}
Y_{t}^{W} & R_{t}^{W} & S_{t}^{W} & C_{t}^{W} & O_{t}^{W} & Y_{t}^{D} & P_{t}^{D} & R_{t}^{D} & E_{t}^{D} & S_{t}^{D}
\end{array}\right]^{T}
$$

As is well known, a structural model for this process can be described in the following way?

$$
A\left(Y_{t}\right)=C(L)\left(Y_{t-1}\right)+B\left(v_{t}\right)
$$

where $A$ is a matrix representing the contemporaneous relations among the variables, $Y_{t}$ is the vector of variables explained above, $C(L)$ is a matrix finite-order lag polynomial, and $v_{t}$ is a vector of structural white noise disturbances. Although this structural model cannot be directly observable, it is possible to compute a VAR model in the reduced form as follows:

$$
\left(Y_{t}\right)=A^{-1} C(L)\left(Y_{t-1}\right)+\left(u_{t}\right)
$$

where $u_{t}$ represents the VAR residual vector, which is normally and independently distributed with full variance-covariance matrix $\Sigma$. From this expression it is possible to show the relation between structural (unobserved) and reduced (observed) shocks:

7 The same steps and definitions as in Favero (2001) are followed. 


$$
A\left(u_{t}\right)=B\left(v_{t}\right)
$$

which implies

$$
\left(u_{t}\right)=A^{-1} B\left(v_{t}\right)
$$

Having now obtained an expression for the observed residuals, it is possible to compute their variance in the following manner:

$$
E\left(u_{t} u_{t}^{T}\right)=A^{-1} B E\left(v_{t} v_{t}^{T}\right) B^{T} A^{-1 T}
$$

And then, by substituting population moments with sample moments, it is possible to obtain:

$$
\hat{\Sigma}=\hat{A}^{-1} \hat{B} I \hat{B}^{T} \hat{A}^{-1 T}
$$

In order to compute this matrix $\hat{\Sigma}$ it is necessary to consider that it has $n(n+1) / 2$ different elements, while there are $2 n^{2}$ unknown elements in the matrices A and B (where $n$ stands for the number of variables in the model) ${ }^{8}$; therefore, a strategy is needed to achieve identification.

The most classical approach to achieve identification was described by Sims (1980), and is based on the Cholesky decomposition. In it, the system is "triangularized" and the identification depends on the ordering of the variables, with a recursive structure where the most endogenous variable corresponds to the last one.

In Chile there are several examples of papers using a recursive identification scheme in VAR models [Bravo et al. (2003) and González (2012), among others], a strategy that is also implemented in this paper. Since the ordering of the variables in this type of identification is crucial, some assumptions are made, and some elements are taken from previous articles.

The first variable corresponds to the demand for Chilean exports, which is followed by the foreign interest rate, the foreign stock markets, and the terms of trade variables ${ }^{9}$. This ordering coincides with that used by Franken, Le fort and Parrado (2005), and also considers the order used by Eichenbaum and Evans (1993) for foreign output and foreign interest rate.

The ordering continues with the domestic variables, where Chilean GDP is followed by domestic prices, domestic interest rate, and the exchange rate. For this ordering it is assumed that the domestic interest rate is not able to affect prices or real variables within a quarter, but it is able to affect the exchange rate, an assumption that

8 For the model used in this paper the matrix $\hat{\Sigma}$ has 55 different elements, while matrices $A$ and $B$ sum up to 200 unknown parameters.

9 Copper was put before Oil; however, to check the validity of this ordering they were also switched in their positions, turning out that the main results of the model remained unaffected. 
is taken from Bravo et al. $(2003)^{10}$. Finally, it is assumed that domestic stock markets are potentially affected by every variable in the model; as a result, they are put in last position, which coincides with Franken, Le fort and Parrado (2005).

By following this ordering, this recursive identification scheme achieves justidentification, having exactly the same amount of unknown elements in matrices $A$ and $B$ than different elements in $\hat{\Sigma}$.

In order to check the robustness of the results, alternative positions for the variables were also revised. In them, the external demand for Chilean exports and the foreign interest rate were kept in first and second place respectively, but changes in the ordering of the rest of the variables were allowed. In these exercises, the results remained mostly unaffected, which also occurred when some variables were replaced by related indicators ${ }^{11}$.

To choose the proper indicator for stock markets, three different models were estimated in which returns, standard deviations or coefficients of variation were included for both foreign and domestic stocks. The Akaike information criterion in the equation for the Chilean GDP was compared among these three different specifications ${ }^{12}$, the result being that the equation for the Chilean GDP in the model including coefficients of variation displayed the smaller value for this criterion; as a result, these indicators were selected to represent foreign and domestic stock markets.

The Akaike information criterion was also used in order to select the lag length, choosing a model with 3 lags, which also satisfied the stability condition, with no root lying outside the unit circle.

Considering the large amount of coefficients to be estimated, two types of test were computed to check whether some variables or lags need not be considered. First, Pair wise Granger Causality tests showed that all of the variables in the model were significant in at least one of the equations of the system. Second, the lag exclusion test showed that endogenous variables were jointly significant for the three selected lags.

As was previously stated, in order to consider features of small open economies some papers have implemented the block exogeneity approach. These type of restrictions emerge from the consideration that a small open economy -such that of Chile- can potentially be affected by variations in foreign variables; however, it should not work the other way around. Because of this, two different procedures were carried out in order to check the validity of the model implemented in this paper.

Firstly, the significance of domestic variables in order to explain foreign ones was checked by using Granger causality tests, as is shown in Table 2. In most cases -except in the case of the international Oil price- domestic variables were not significant in order to explain foreign ones, as was expected.

10 The authors make this assumption for the monetary policy rate, which is highly correlated to the domestic interest rate used in this paper, especially from 2001 onwards.

11 For instance, the MSCI World index was replaced by the Dow Jones (total) index.

12 This criterion was selected because of its better properties in small samples according to Lütkepohl (2005). 


\section{TABLE 2}

\section{GRANGER CAUSALITY TESTS}

\begin{tabular}{|c|c|c|c|c|c|c|c|c|c|c|}
\hline & \multicolumn{2}{|c|}{$\begin{array}{l}\text { Chilean } \\
\text { GDP }\end{array}$} & \multicolumn{2}{|c|}{$\begin{array}{l}\text { Domestic } \\
\text { Prices }\end{array}$} & \multicolumn{2}{|c|}{$\begin{array}{c}\text { Domestic } \\
\text { Interest } \\
\text { Rate }\end{array}$} & \multicolumn{2}{|c|}{$\begin{array}{l}\text { Exchange } \\
\text { Rate }\end{array}$} & \multicolumn{2}{|c|}{$\begin{array}{l}\text { Domestic } \\
\text { Stocks }\end{array}$} \\
\hline & Chi-sq & Prob. & Chi-sq & Prob. & Chi-sq & Prob. & Chi-sq & Prob. & Chi-sq & Prob. \\
\hline $\begin{array}{l}\text { Demand for } \\
\text { Chilean Exports }\end{array}$ & 4.17 & 0.24 & 11.94 & 0.01 & 12.31 & 0.01 & 1.84 & 0.61 & 5.68 & 0.13 \\
\hline $\begin{array}{l}\text { Foreign Interest } \\
\text { Rate }\end{array}$ & 3.37 & 0.34 & 2.88 & 0.41 & 2.25 & 0.52 & 3.16 & 0.37 & 4.62 & 0.20 \\
\hline $\begin{array}{l}\text { Foreign } \\
\text { Stocks }\end{array}$ & 0.95 & 0.81 & 6.12 & 0.11 & 3.42 & 0.33 & 1.10 & 0.78 & 8.16 & 0.04 \\
\hline $\begin{array}{l}\text { Copper } \\
\text { (International Price) }\end{array}$ & 2.15 & 0.54 & 10.41 & 0.02 & 6.31 & 0.10 & 3.07 & 0.38 & 2.80 & 0.42 \\
\hline $\begin{array}{l}\text { Oil } \\
\text { (International Price) }\end{array}$ & 12.05 & 0.01 & 13.24 & 0.00 & 13.49 & 0.00 & 6.94 & 0.07 & 13.10 & 0.00 \\
\hline
\end{tabular}

Source: Author's computation.

Secondly, the unrestricted model implemented here was compared with three alternative specifications, in which different restrictions were imposed in the lag structure. In the first one, the demand for Chilean exports, the foreign interest rate, and foreign stock markets were just affected by the lags of themselves and the lags of each other. Both the Copper and the Oil price were only affected by the lags of the first three variables plus the lags of themselves, and the five domestic variables were affected by the lags of all the variables in the model. In the second specification, the first three variables were furthermore affected by the lags of the Oil price. Finally, in the last alternative specification, additional restrictions were included for domestic prices and the domestic interest rate, which were just affected by the lags of the foreign interest rate, plus the lags of domestic output, prices, interest rate, and exchange rate.

These three alternative specifications were compared with the unrestricted model, by computing the likelihood ratio test with the modification introduced by Sims and mentioned by Hamilton (1994) for small samples ${ }^{13}$. The results showed that the

13 The test had the form:

$(T-k)\left\{\log \left|\hat{\Omega}_{0}\right|-\log \left|\hat{\Omega}_{1}\right|\right\}$, with a $x^{2}$ distribution with degrees of freedom equal to the number of restrictions imposed, and $\left|\hat{\Omega}_{0}\right|$ corresponding to the determinant of the variance-covariance matrix of the residuals of the restricted model, $\left|\hat{\Omega}_{1}\right|$ to the same value for the unrestricted model, and $k$ to the number of parameters estimated per equation. 
dynamics were not completely captured by these restricted specifications, seeming preferable the unrestricted model implemented in this paper.

\section{RESULTS}

\section{Effects of foreign financial shocks on the Chilean Economy}

Concerning the main purpose of this paper, this section starts with the response of domestic variables to shocks in foreign stock markets, including the response of the Chilean GDP to these types of innovations.

The response of the volatility of domestic stocks to these types of shocks is positive, although not significant, while the domestic interest rate responds both negatively and significantly, which is shown in Figure 6. Local investors, when facing higher volatility in both foreign and domestic stock markets, could increase their positions in domestically issued debt securities, decreasing the interest rate associated with these types of instruments.

The response of domestic prices is positive -although not significant- while the exchange rate reacts positively and significantly, which is shown in Figure 7. The positive response of domestic prices can be related to the fall in the domestic interest rate, which might also produce an outflow of capital from the Chilean Economy, reducing the supply of foreign currency ${ }^{14}$. Besides, due to the higher volatility in stock markets, local investors could be increasing their positions in foreign currencies, increasing the demand in the foreign exchange market.

Finally, and answering the main question of this paper, the response of the Chilean GDP to shocks in the volatility of international stock markets is negative and significant, and achieves its largest effect in the second quarter as can be seen in Figure 8. This negative response of the Chilean GDP would not be expected taking into account the depreciation of the domestic currency and the fall in the domestic interest rate; however, it must be considered that the model is estimated using quarterly frequency data. The effect of both the exchange rate and the domestic interest rate is probably transmitted to the GDP in subsequent periods; nevertheless, some of its components -such as consumption and investment- might be affected promptly and significantly by these types of innovations.

Comparing these results with those found in similar studies, it can be mentioned that Rapach and Strauss (forthcoming) in their work on business-cycle fluctuations in G-7 countries include a Financial Conditions Index (FCI), which considers first

14 Although the foreign interest rate also showed a negative response to this type of shocks, the magnitude of its response was smaller. As a result, the interest rate differential could probably decrease, generating an outflow of capital from the Chilean economy. 


\section{FIGURE 6}

RESPONSES OF DOMESTIC STOCKS VOLATILITY (LEFT) AND DOMESTIC INTEREST RATE (RIGHT) TO CHOLESKY ONE S.D. IN FOREIGN STOCKS VOLATILITY INNOVATION
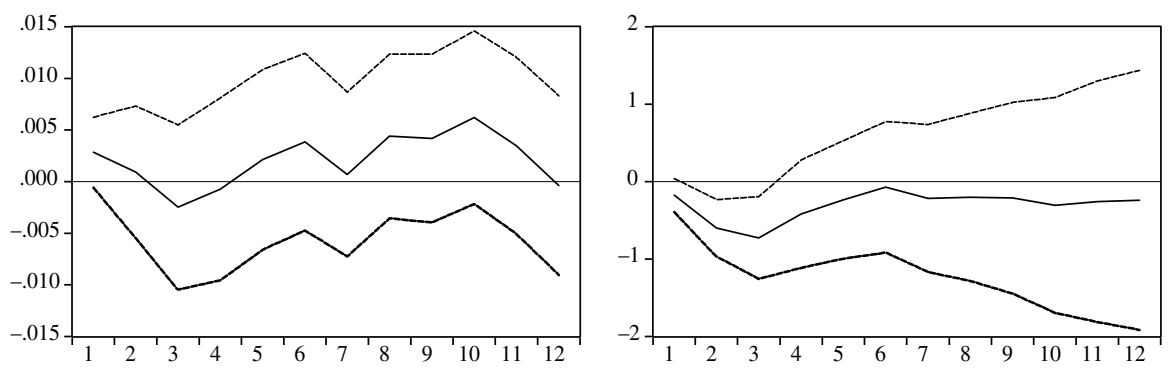

FIGURE 7

RESPONSES OF DOMESTIC PRICES (LEFT) AND EXCHANGE RATE (RIGHT) TO CHOLESKY ONE S.D. IN FOREIGN STOCKS VOLATILITY INNOVATION
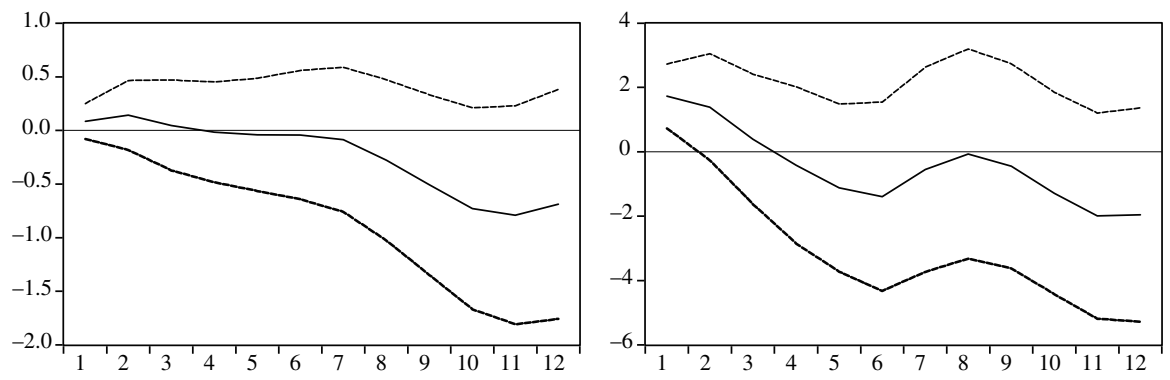

principal component from different spreads, stock market volatility, real financial sector stock return, among other financial variables ${ }^{15}$.

In their results when they include this FCI as a financial sector variable, they find negative and significant responses of $(\log )$ industrial production to a financial sector shock in five of the G-7 countries, while in the case of Italy and Japan they find negative though not significant responses. Besides, responses of short-term rates to these types of innovations for six of the G-7 countries (except for Japan) appear to be negative and significant. The results found in this paper coincide with these.

15 Details of this paper are not available since this work has not still been published. 


\section{FIGURE 8}

RESPONSE OF THE CHILEAN GDP TO CHOLESKY ONE S.D. IN FOREIGN STOCKS VOLATILITY INNOVATION

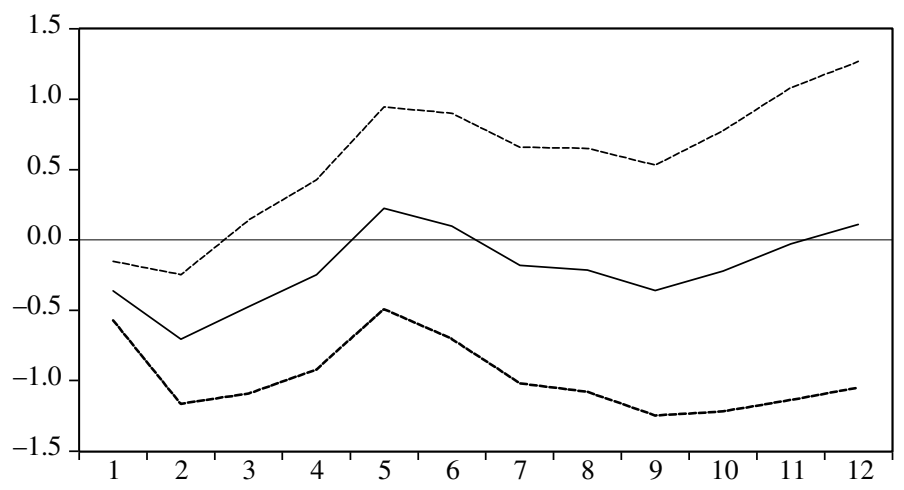

The response of the Chilean GDP previously mentioned also coincides with that found by Franken, Le Fort y Parrado (2005) who showed that an increase in the volatility of world equities caused a negative effect on the Chilean business cycle ${ }^{16}$.

\section{Effects of other shocks explained by the model}

Impulse response functions show that the model also enables other features of the Chilean Economy to be explained.

The response of the domestic interest rate to shocks in the demand for Chilean exports is found to be positive and significant in some periods. This is expected under the assumption that a positive shock in the demand for Chilean exports should positively affect the Chilean GDP; as a result, the domestic interest rate needed to be increased; however, the response of the Chilean GDP to these type of innovations is found not to be significant. The exchange rate responds negatively and significantly, which can be explained by the higher supply of foreign currency in the Chilean economy. All of these results are displayed in Figure 9.

16 These authors used deviations of $\log$ from HP trend for Chilean Output. 


\section{FIGURE 9}

\section{RESPONSES OF DOMESTIC INTEREST RATE (LEFT), CHILEAN GDP (RIGHT) AND EXCHANGE RATE (BELOW) TO CHOLESKY ONE S.D. IN DEMAND FOR CHILEAN EXPORTS INNOVATION}
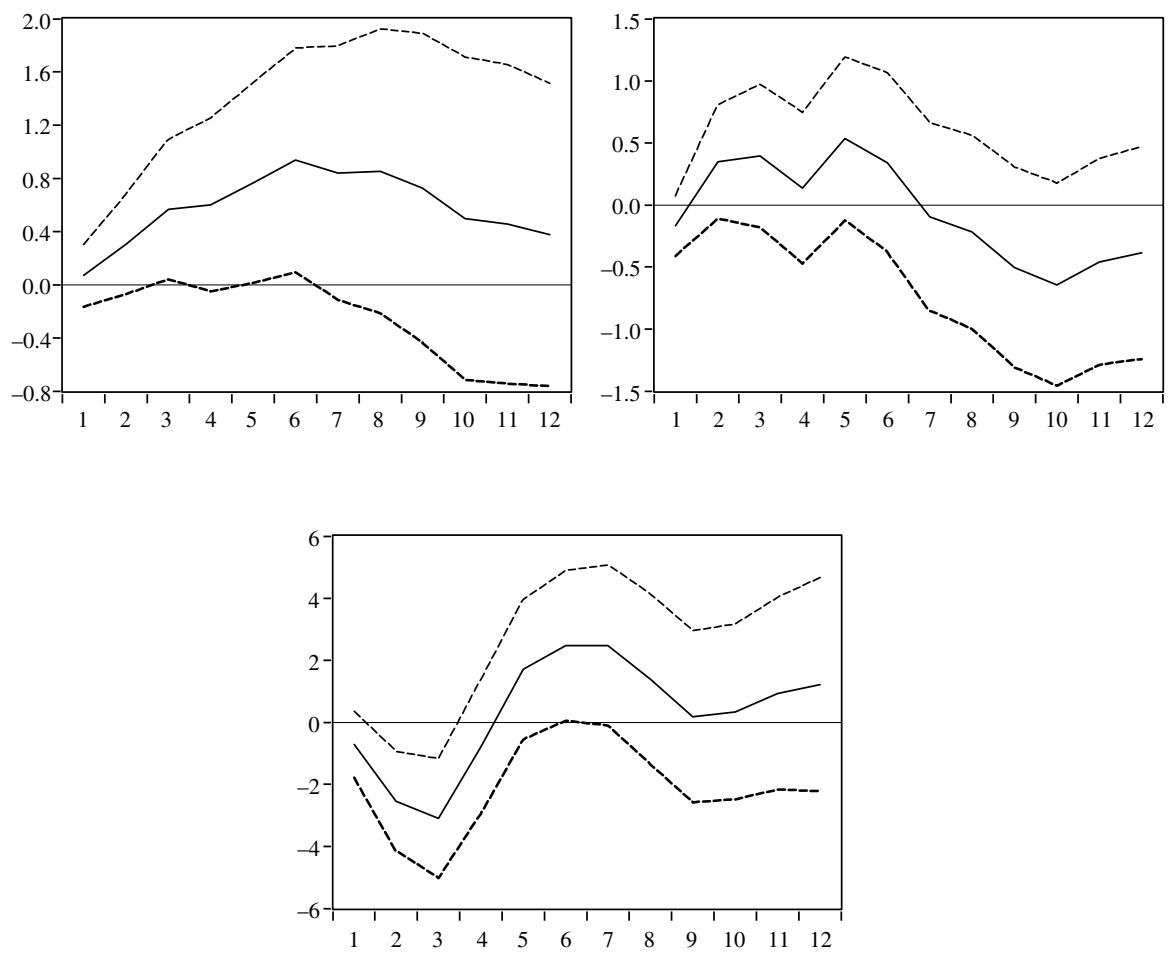

Figure 10 shows the responses of the Chilean GDP to shocks in Copper and Oil prices. As expected, shocks in the price of Copper have a positive -although not significant-impact on the Chilean GDP, while the effect of shocks in the Oil price is positive at the beginning, and becomes negative and significant only in the fifth period. Only this latter and significant response of the Chilean GDP to shocks in the Oil price is as expected.

Regarding domestically driven shocks, the Chilean GDP reacts significantly and negatively to shocks in domestic prices, a response that is as expected, and it is shown in Figure 11. On the other hand, responses to other domestic innovations did not appear to be significant. 
FIGURE 10

RESPONSES OF CHILEAN GDP TO CHOLESKY ONE S.D.

IN COPPER PRICE (LEFT) AND OIL PRICE (RIGHT) INNOVATION
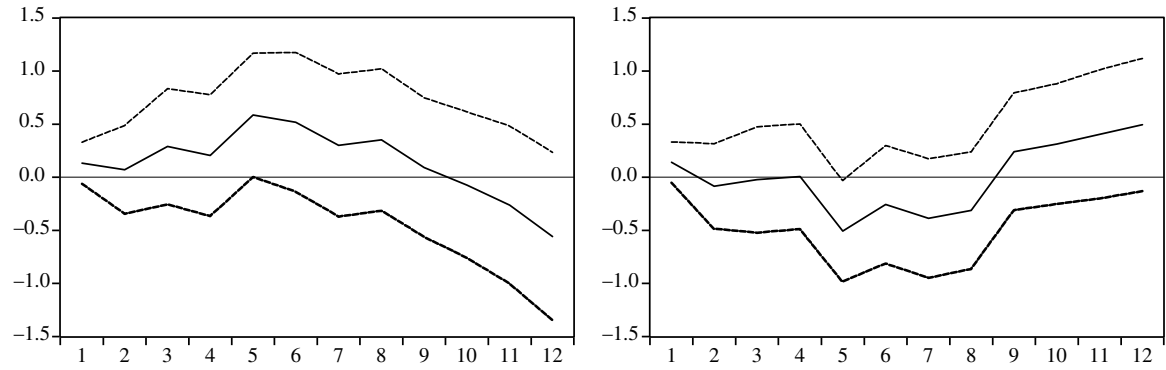

FIGURE 11

RESPONSE OF CHILEAN GDP TO CHOLESKY ONE S.D. IN DOMESTIC PRICES INNOVATION

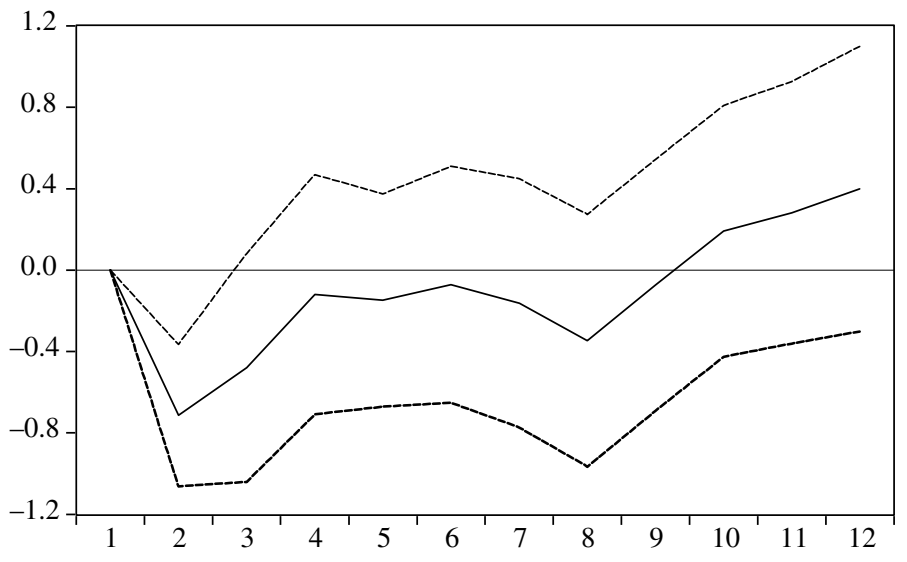

\section{CONCLUSIONS}

This paper has aimed to assess the effect of disturbances in foreign stock markets on the Chilean economy, for which a VAR model with quarterly frequency data -including real and financial series for both foreign and domestic variables- has been estimated. 
The model corresponds to an unrestricted VAR and implements a recursive identification scheme; its ordering has been chosen considering previous developments and also some assumptions, and its robustness has been checked by comparing the results to alternative specifications. Furthermore, considering that Chile is a small open economy -and therefore it is potentially affected by foreign variables but not big enough to affect them in the opposite direction- its capability to properly measure the main features of the Chilean economy has also been revised.

Among the main results, it is found that the Chilean GDP responds negatively and significantly to shocks in the volatility of foreign stock markets, while the Chilean currency depreciates and the domestic interest rate decreases due to these types of innovations. Besides, the model also enables the responses of the Chilean economy to other type of shocks to be explained.

Further developments might compare the responses of the Chilean case to other emerging economies. Besides, a disaggregation of components of the GDP-considering for instance consumption and investment- could help to describe, in a more precise manner, the effect of these type of shocks on real domestic variables.

\section{REFERENCES}

BERNANKE, B., M. GERTLER and S. GILCHRIST (1999). "The Financial Accelerator in a Quantitative Business Cycle Framework”, in Handbook of Macroeconomics 1, pp. 1341-1393.

BRAVO, H., C. GARCIA, V. MIES and M. TAPIA (2003). "Heterogeneidad de la transmisión monetaria: Efectos Sectoriales y Regionales", Economía Chilena 6(3), pp. 5-26.

BUCKLE, R., K. KIM, H. KIRKHAM, N. MCLELLAN and J. SHARMA (2002). "A structural VAR model of the New Zealand business cycle", New Zealand Treasury Working Paper 02/26. Wellington: New Zealand Treasury.

CAPUTO, R., J.P. MEDINA and C. SOTO (2010). "The financial accelerator under learning and the role of monetary policy", Working Papers Central Bank of Chile, N 590. Santiago: Central Bank of Chile.

CAPUTO, R., J.P. MEDINA and C. SOTO (2011). "Understanding the impact of the global financial shock on the Chilean Economy", paper prepared for the 2nd BIS CCA Conference on "Monetary policy, financial stability and the business cycle". Ottawa, 12-13 May 2011, available at <http://www.bis. org/events/ccaconf2011/caputo.pdf> [18 May 2012].

CATÃO, L. and A. PAGAN (2010). "The Credit Channel and Monetary Transmission in Brazil and Chile: A Structural VAR Approach", Working Papers Central Bank of Chile, No 579. Santiago: Central Bank of Chile.

CHUMACERO, R. and K. SCHMIDT-HEBBEL (2004). "General Equilibrium Models: An Overview", Working Papers Central Bank of Chile, No 307. Santiago: Central Bank of Chile.

CUSHMAN, D. and T. ZHA (1997). "Identifying monetary policy in a small open economy under flexible exchange rates", Journal of Monetary Economics 39, pp. 433-448.

EICHENBAUM, M. and C. EVANS (1993). "Some empirical evidence on the effects of monetary policy shocks on exchange rates", NBER Working Papers No 4271. Cambridge, MA: National Bureau of Economic Research.

FAVERO, C. (2001). Applied Macroeconometrics, Oxford: University Press.

FRANKEN, H., G. LE FORT and E. PARRADO (2005). "Business Cycle Dynamics and Shock Resilience in Chile", Working Papers Central Bank of Chile, No 331. Santiago: Central Bank of Chile.

FRANSES, P. and H. MEES (2010). “Approximating the DGP of China's Quarterly GDP”, Econometric Institute Report EI 2010-04, Erasmus University Rotterdam, Econometric Institute.

GARCIA, C., P. GONZALEZ and A. MONCADO (2010). "Proyecciones Macroeconómicas en Chile: Una Aproximación Bayesiana”, ILADES-Georgetown University Working Papers inv262, IladesGeorgetown University, Universidad Alberto Hurtado/School of Economics and Business. 
GILCHRIST, S., A. ORTIZ and E. ZAKRAJŠEK (2009). "Credit Risk and the Macroeconomy: Evidence from a Estimated DSGE Model", Unpublished manuscript Boston. [Online] available from <http:// www.mendeley.com/research/credit-risk-and-the-macroeconomy-evidence-from-an-estimated-dsgemodel/> [10 August 2011].

GONZALEZ, W. (2012). "Un gran VAR Bayesiano para la Economía Chilena”, Working Papers Central Bank of Chile, $\mathrm{N}^{\circ}$ 653. Santiago: Central Bank of Chile.

HAMILTON, J. (1994). Time Series Analysis, Princeton, New Jersey: Princeton University Press.

JARAMILLO, P. (2008). "Estimación de VAR Bayesianos para la Economía Chilena", Working Papers Central Bank of Chile, $\mathrm{N}^{\circ}$ 508. Santiago: Central Bank of Chile.

JERMANN, U. and V. QUADRINI (2009). "Macroeconomic Effects of Financial Shocks", NBER Working Paper $\mathrm{N}^{\mathrm{o}}$ w15338, available at <http://ssrn.com/abstract=1472276> [01 September 2011].

LÜTKEPOHL, H. (2005). New Introduction to Multiple Time Series Analysis, Berlin: Springer.

MIES, V., F. MORANDE and M. TAPIA (2002). "Política Monetaria y Mecanismos de Transmisión: Nuevos Elementos para una Vieja Discusión”, Working Papers Central Bank of Chile, № 181. Santiago: Central Bank of Chile.

MSCI (2011). "Index Definitions" [online] available from <http://www.msci.com/products/indices/tools/ index.html\#WORLD> [15 August 2011]

PARRADO, E. (2001). "Shocks Externos y Transmisión de la Política Monetaria en Chile", Economía Chilena 4(3), pp. 29-57.

RAPACH, D. and J. STRAUSS (Forthcoming). "Financial Sector Shocks and G-7 Business-Cycle Fluctuations" [online]. Slides for 2011 Midwest Econometrics Group Meetings available at <http:// sites.slu.edu/rapachde/> [26 March 2012]. (Preliminary version of the paper coming soon).

SIMS, C. (1980). "Macroeconomics and reality", Econometrica 48(1), pp. 1-48.

VALDES, R. (1997). “Transmisión de Política Monetaria en Chile”, Working Papers Central Bank of Chile, $\mathrm{N}^{\circ}$ 16. Santiago: Central Bank of Chile. 


\section{APPENDIX}

Details for each one of the series ${ }^{17}$ :

1. External demand for Chilean exports $\left(Y^{W}\right)$ : Firstly, information for Chilean exports with destinations, for the period 1997 to 2010, was obtained from the National Customs Service of Chile, at yearly frequency. The sum of exports to the USA, European Union, China and Japan was later computed, with these four destinations roughly representing 60 percent of the total of Chilean exports for each year. Then, a share for each of these destinations was calculated as the exports to each one, over the sum of the four of them for each year. Secondly, GDP growth rates for the USA, Euro Zone and Japan were taken from the Central Bank of Chile website, at quarterly frequency. The GDP growth rate for China was obtained from Franses and Mees (2010) for the period 1997Q3 to 2009Q4, and from the National Bureau of Statistics of China from 2010Q1 to 2010Q4. Finally, for each quarter, this series was calculated as the weighted average of the quarterly growth rate for each destination, using the share of each one of them as the weight within each year.

2. Foreign interest rate $\left(R^{W}\right)$ : Firstly, information for GDP (expenditure approach) was taken from the OECD's website, in US dollars (constant prices), at yearly frequency. The sum of the GDP of USA, China, Japan, Germany and United Kingdom was computed, with these countries roughly representing 65 percent of the GDP of all OECD's countries plus China in each year of the period. Then, a share for each of these countries was calculated as the GDP of each one, over the sum of the five of them. Secondly, the short term rate for these countries was obtained also from the OECD, which corresponds to either the three month interbank offer rate or to the rate associated with Treasury bills, Certificates of Deposit or comparable instruments, each of three month maturity. However; the information for Japan was just available from 2002Q2 onwards. In order to replace the information for Japan, Japan's interbank rates for 3 months were taken from DataStream, at daily frequency, and the average for each quarter was computed. Finally, for each quarter the foreign relevant short term interest rate was calculated as the weighted average of the quarterly interest rate of these countries, using for Japan the interbank rate for three months, and the share previously computed for each country as the weight within each year.

3. Foreign stock markets $\left(S^{W}\right)$ : The data was obtained from DataStream, at daily frequency for the period 1997 to 2010, information that was used to compute the average, the standard deviation, and the coefficient of variation of each quarter.

17 The symbol * stands for series that have been computed as the difference between the natural logarithm of each quarter and the natural logarithm of the same quarter of the previous year, multiplied by 100 . 
It corresponds to the MSCI World Index, which measures the equity market performance of 24 developed markets ${ }^{18}$.

4. International price of Copper $\left(C^{W}\right)$ : The information was obtained from the Central Bank of Chile website, at quarterly frequency. It corresponds to the price (in dollars per pound) of refined copper on the London Metal Exchange*.

5. International price of Oil $\left(O^{W}\right)$ : The information was obtained from the Central Bank of Chile website, at quarterly frequency. It corresponds to the price (in dollars per barrel) of WTI crude oil*.

6. Growth rate of the Chilean Economy $\left(Y^{D}\right)$ : The information was obtained from the Central Bank of Chile website, at quarterly frequency. It corresponds to the spliced series for the Chilean GDP, base 2003, at constant prices, seasonally adjusted*.

7. Domestic Prices $\left(P^{D}\right)$ : The information was obtained from the Central Bank of Chile website, at quarterly frequency. It corresponds to the historical series for the Headline CPI (index average $2009=100$ )*.

8. Domestic interest rate $\left(R^{D}\right)$ : The information was obtained from the OECD's web site, at quarterly frequency. It corresponds to either the three month interbank offer rate or the rate associated with Treasury bills, Certificates of Deposit or comparable instruments, each of three month maturity. However, the values for both the third quarter of 2008 and the second quarter of 2010 were missed. In order to compute these two values, interest rates of discountable promissory notes tendered by the Central Bank of Chile in pesos (PDBC) were taken from its web site, at monthly frequency and annual basis. The short interest rate for the missed values was obtained as the average of the 30 days notes for each quarter, plus the average premium between the 30 and 90 days notes for the same year.

9. Exchange Rate $\left(E^{D}\right)$ : The information was obtained from the Central Bank of Chile website, at quarterly frequency. It corresponds to the multilateral exchange rate, which represents the nominal component of the real exchange rate*.

10. Domestic stock market $\left(S^{D}\right)$ : The data was obtained from DataStream, at daily frequency for the period 1997 to 2010, information that was used to compute the average, the standard deviation, and the coefficient of variation of each quarter. It corresponds to the index IPSA, which is composed of the 40 most heavily traded stocks on the Santiago Stock Exchange.

18 "The MSCI World Index consists of the following 24 developed market country indices: Australia, Austria, Belgium, Canada, Denmark, Finland, France, Germany, Greece, Hong Kong, Ireland, Israel, Italy, Japan, Netherlands, New Zealand, Norway, Portugal, Singapore, Spain, Sweden, Switzerland, the United Kingdom, and the United States". (Source: MSCI website) 
